\title{
THE STATE IS NOT PRESUMED TO BE BOUND BY STATUTE - A CONSTITUTIONAL AND JURISPRUDENTIAL ANACHRONISM
}

GE Devenish

BSc LLB LLD TTHD

Senior Research Associate

University of KwaZulu-Natal, Durban

\section{SUMMARY}

The presumption that the state is not bound by legislation has its genesis and lineage in our common law. It is a controversial presumption that needs to be evaluated carefully in the light of the libertarian provisions of both our common law and the Constitution. In particular, section 2 of the South African Constitution declares the Constitution to be the supreme law. Section 1 enshrines the common law concept of the rule of law, which is also given expression to in the provisions of the Bill of Rights. The latter section of the Constitution prescribes the rule of law as one of the seminal libertarian values on which the Constitution is founded. The concept of the rule of law is a fundamental value that underlies "an open and democratic society based on dignity, equality and freedom", and must be promoted when interpreting the provisions of the Bill of Rights. Furthermore, section 39(2) of the Constitution stipulates that the principles and rules of our common law must be developed in accordance with the spirit and ethos of the fundamental rights in the Constitution. This article addresses the formidable challenge posed by the sections of the Constitution referred to above and the common law, to the presumption that the state is not bound by legislation.

\section{$1 \quad$ INTRODUCTION}

The presumption that the state is not bound ${ }^{1}$ has its genesis and lineage in our common law, as will be explained in this article. It is a controversial presumption and needs to be evaluated carefully in the light of the libertarian provisions of both our common law and the Constitution. However, before considering this specific presumption that the state is not bound by statute, it is necessary to consider the jurisprudential nature and ethos of the interpretative presumptions in general.

Statutory construction is inextricably involved with a jurisprudential phenomenon described as the presumptions of interpretation. These putatively designated "presumptions of legislative intent are misnomers"

See Labuschagne "Die Uitlegvermoede teen Staatsgebondenheid" 19783 TRW 4243.

Hahlo and Kahn The South African Legal System and Its Background (1968) 202. 
since they refer to certain assumptions which, according to Pearce and Geddes, are premised "on the expectation that certain basic tenets of our legal system will be followed by the legislature". ${ }^{3}$ The so-called presumptions are therefore common-law a priori guidelines and principles of law, employed to assist the courts in the process of construing the law, whereas an authentic presumption of law is an arbitrary conclusion attached to particular facts, either conclusive or rebuttable. In practice, however, the terms "assumption" and "presumption" are used indiscriminately, although the latter term has a far greater frequency of use in legal scholarship, curial language and writing. These principles, as du Plessis perceptively explains, are "legal standards that, unlike rules, do not operate in an all-or-nothing fashion".

The authors Hahlo and Khan ${ }^{5}$ classified the presumptions as merely tertiary sources to be applied "where uncertainty prevails after invocation of the objective primary and secondary rules of construction". ${ }^{6}$ However, this classification is a patent oversimplification and is incompatible with the perception of certain key presumptions, applied by our courts since "many instances can be found where the presumptions were applied to get at the meaning of the legislation where prima facie the wording was unambiguous" (author's own emphasis). ${ }^{7}$ In support of this view Cross remarks, with regard to certain presumptions, that "they apply although there is no question of linguistic ambiguity in the statutory wording under consideration and they may be described as presumptions of general application". ${ }^{8}$ In similar vein the Canadian scholar, Driedger, provides the following compendious explanation of the role and function of the presumptions:

"These are firmly incorporated in our jurisprudence and should always be kept in mind in construing statutes ... and not only to those that are found to be defective. Every statute involves language, a legislative scheme, and a declared and presumed intent of Parliament" (author's own emphasis). ${ }^{9}$

Cowen expresses a similar perception in regard to the presumptions:

"To begin with, many of the relevant presumptions are legal principles, comprising a basic or fundamental part of the legal system. Statutes ... are not isolated phenomena, but should be integrated or harmonized with the whole legal system of which they form a part. It follows, therefore, that such presumptions should be taken into account by the interpreter, right from the outset, no matter how wide and general, and no matter how seemingly clear, the words of the enactment may seem when considered in isolation. Furthermore, when all the relevant contextual considerations have been duly

3 Pearce and Geddes Statutory Interpretation in Australia (1996) 81.

4 Du Plessis Re-Interpretation of Statutes (2002) 149. See also Dworkin Taking Rights Seriously (1977) 22-28.

5 202; and see also Celliers "Die Betekenis van Vermoedens by Wetsuitleg" 196279 SALJ 189203.

6 Hahlo and Kahn 202; and see also Cockram Interpretation of Statutes (1987) 77 who comments that "[p]resumptions are used by the court to interpret ambiguous texts".

7 Du Plessis 150; and see also Hahlo and Kahn 202. The example given by Hahlo and Kahn in Phillips v Direkteur vir Sensus 1959 3 SA 370 (A); and cf Cockram 77.

8 Cross Statutory Interpretation (1976) 143.

$9 \quad$ Driedger The Composition of Legislation (1956) 163. 
weighed, the interpreter should again test his conclusions in the light of the presumptions" (author's own emphasis).

Du Plessis ${ }^{11}$ presents three possibilities in this regard:

(1) presumptions are mere tertiary or "last resort" sources;

(2) the "middle view" according to which the presumptions always qualify the provisions of statutes; or

(3) the view that "the presumptions are the ABCs as well as the XYZs" of statutory interpretation and that interpretation should therefore "both begin and end with ... presumptions". ${ }^{12}$

The third viewpoint is the one advocated by the writer of this article and as a result used to explain the nature and characteristics of the presumptions. ${ }^{13}$ Furthermore, as explained by Cowen, they are fundamental principles of our legal system, reflected in the common law and are now given cogent expression to in the provisions of the South African Bill of Rights.

Cross observes that the presumptions of general application should be distinguished from those "for use in doubtful cases". ${ }^{14}$ The latter obviously do not carry the same weight as the former, as they are only applicable where the language of a provision is equivocal. The presumptions of interpretation encapsulate seminal legal and jurisprudential principles ${ }^{15}$ of the common law that should be employed in the process of interpretation. In addition Cross comments that

"certain presumptions also operate in a constitutional context since they are expressions of fundamental principles governing the relations between Parliament, the executive and the courts".

According to Pearce, the presumptions are "recognised principles that Parliament would be prima facie expected to respect". 17 The legislature and the parliamentary draftsman, use the device of ellipsis, ${ }^{18}$ which is a

10 Cowen "The Interpretation of Statutes and the Concept of 'the Intention of the Legislature", 198043 THRHR 374 391. In order to support this viewpoint Cowen refers to dicta from the following cases: Dadoo Ltd v Krugersdorp Municipal Council 1920 AD 530 552; and Union Government v Tonkin 1918 AD 533545.

11 Interpretation of Statutes (1986) 52.

12 lbid.

13 Cf Du Plessis (1986) 53 who comments in this regard that "dicta to the effect that the presumptions operate even though the wording is clear and unambiguous must necessarily imply that there is sufficient room for at least the second, but perhaps even the third view to be implemented".

14 Bell and Engle Cross Statutory Interpretation (1987) 167.

15 In this regard Hahlo and Kahn 202 state: "They are more than simply methods of legal approach, however, being rules of the common law." See also Wiechers "Die Bronne van die Administratiefreg" 196629 THRHR 103 112; and Wiechers Administrative Law (1985) 44: "Presumptions of interpretation are legal rules which qualify the legislature's legislative measures." Du Plessis (1986) 54 who regards them as "material groundnorms of interpretation, on the same level as similar policy-determined groundnorms in other fields of law ..."

16 Cross 143

17 Pearce and Geddes 129.

18 Bennion Statutory Interpretation (1983) 251-252. 
technique employed to take these general principles for granted in the process of interpretation. This applies to the interpretation of all literature and not only to legal documents. Posner in his brilliant book Law and Literature $^{19}$ explains that

"[e]verybody understands that a writing is intelligible only in a context, that is, only in terms of presuppositions regarding language and culture and that the reader brings with him rather than finds in the text".

Interpretation of legislation therefore involves a synthetic process of inference not only from linguistic but also from legal and jurisprudential indicia. The process of interpretation should therefore be a holistic one in which the presumptions of interpretation, which embody normative principles of a libertarian common law, constitute an indispensable source for precipitating and applying the intention of the legislature. Steyn aptly expressed the position as follows:

"Die woorde van 'n wet is ... nie die uitsluitlike kenbron van die wil van die wetgewer nie. Sy wilsinhoud blyk in 'n aansienlike mate ook uit weerlegbare vermoedens."

The presumptions and their application shed light on the nature of the interpretative process as well as the symbiotic relationship which exists between statute and common law in this process. The presumptions of interpretation are a dynamic jurisprudential phenomenon that have evolved and continue to evolve out of judicial interpretation. They do not therefore constitute a numerus clausus but, as Du Plessis ${ }^{21}$ comments, they "serve as basic guidelines throughout the process of interpretation". The specific presumption that the state is not bound by legislation will be discussed in the light of the general nature of the presumptions, which reflect the libertarian nature of our common law. In this regard Pearce perceived the presumptions as "the court's effort to provide, in effect, a common law Bill of Rights - a protection for the civil liberties of the individual against invasion by the state". ${ }^{22}$ This is an important idea and it indicates quiet clearly that the presumptions reflect that which is good, honourable and fair in our common law, bearing in mind that Roman-Dutch common law had its roots in natural law. ${ }^{23}$

Many of the common law presumptions have been subsumed into the provisions of the Bill of Rights in the South African Constitution. As a result,

19 (1988) 222.

20 Steyn Uitleg van Wette (1981) 69. Singer Sutherland Statutory Interpretation (1986) Vol 2A 67 par 45.113 expresses a similar sentiment: "[T] he process of construction is conditioned by the various presumptions which the courts apply consistently. Because they are standard factors, regularly applied, they can be counted among aids and guides or resources of interpretation."

21 (1986) 55.

22 Pearce and Geddes 129. See also Willis "Statute Interpretation in a Nutshell" 193816 Canadian Bar Review 117.

23 See Wessels The History of Roman-Dutch Law (1908) 327. In this regard Voet comments "that law is a branch of morals and that the judge in interpreting the law must always bear in mind the fact that the ultimate end and object of all law are to regulate relations of individuals according to that sense of right and wrong that prevails in the community ..." 
Du Plessis informs us that "most opinions that have so far been expressed on the future of the presumptions foresee a substantially lesser and more limited role for them". ${ }^{24}$ Nevertheless, they have still "been invoked in constitutional interpretation". ${ }^{25}$ It is important to note that, "reliance on the presumptions has not visibly abated since $1994 ",{ }^{26}$ according to De Ville. ${ }^{27}$ Burns, ${ }^{28}$ however, foresaw a limited role for the presumptions under the new constitutional dispensation. This is clear from her statement that: "Before the promulgation of the interim and 1996 Constitutions, the common
law presumptions of statutory interpretation played a vital role in the protection
of individual rights and freedoms ... These presumptions, which could be
regarded as a common law bill of rights, have now largely been supplanted by
the supreme constitution in general, and the chapter on fundamental rights in
particular. In effect most of the presumptions have been codified as
entrenched fundamental rights."

Botha is of a similar viewpoint. ${ }^{29}$ It is also apparent from the judgment of the Constitutional Court in The Pharmaceutical Manufacturers Association of $S A$. In re The Ex parte Application of the President of the $R S A^{30}$ that the common law presumptions, in relation to the controlling of public power, are now subject to and in some cases have been subsumed into the provisions of the Bill of Rights, as interpreted and invoked by the courts for the purpose of both statutory and constitutional interpretation. The court did, however, emphasize that the common law rules, in so far as they continue to be relevant in judicial assessments of the exercise of public power, gain force from the Constitution. Furthermore, and most important, it held that the Constitution and the common law are intertwined and therefore "do not constitute separate concepts".

It is therefore submitted that the presumptions, as interpretative principles, continue to fulfil certain beneficial functions. They can for instance be used, as Du Plessis explains, ${ }^{31}$ to give expressions to section $39(2)$ of the Constitution which states that "when interpreting any legislation, and when developing the common law or customary law, every court, tribunal or forum must promote the spirit, purport and objects of the Bill of Rights". Secondly, as Du Plessis further explains, ${ }^{32}$ they can be used to advance foundational "values consistent with but not spelled out in the Constitution". Lastly, in this regard, they can amplify and guide constitutional values found in the constitution and its interpretation respectively.

There is no doubt, as Botha explains, ${ }^{33}$ that the role and character of the presumptions have been fundamentally changed, with the inception of the

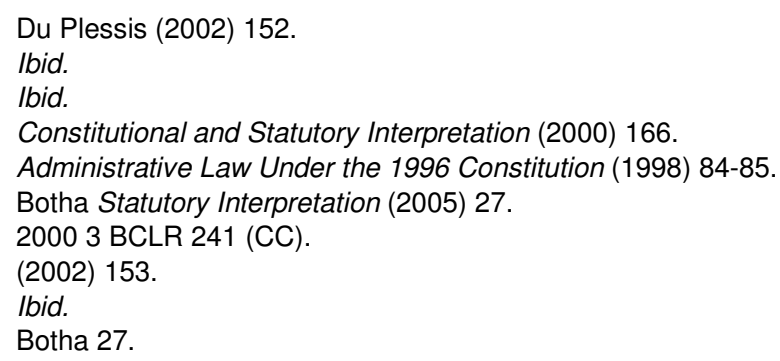


new constitutional dispensation. These presumptions are to a large extent now reflected in the provisions of the Bill of Rights. As such they are now entrenched and cannot be infringed by the legislature or disregarded by the courts. ${ }^{34}$ They have not been, it must be emphasised, abrogated by the Constitution, but they need no longer be relied on as a de facto Bill of Rights, and reliance on them is likely to diminish in the future. Nevertheless, the presumptions are deeply entrenched in our law and legal literature and they continue to be relevant and must now reflect in general the values and ethos of the Bill of Rights. Their operation is not static and they must as part of our common law, be developed in accordance with section 39(2) which requires that they be promoted in accordance with "the spirit, purport and objects of the Bill of Rights".

\section{THE SPECIFIC PRESUMPTION THAT THE STATE IS NOT BOUND BY LEGISLATION}

Bearing in mind the libertarian nature of the presumptions as a whole, as illustrated above this specific presumption must be carefully examined. Steyn in his book observed ${ }^{35}$ that this presumption is merely a means of attempting to establish the intention of the legislature. It is therefore, according to him, a rule of interpretation and not a definition of a prerogative. ${ }^{36}$ However, it is now accepted that the presumption had its origin in the Crown's (the executive's) prerogative powers, ${ }^{37}$ which are a constitutional phenomenon that was preserved in South Africa by section 7 the 1983 Constitution. ${ }^{38}$ However, it is submitted that in view of the fact that the Constitution is declared to be the supreme law these ancient common law powers are no longer operative.

The rule can be traced back to the maxim of princeps legibus solutus est ${ }^{39}$ (the State is not bound by the law) which Wiechers explains by stating that

"the State possesses a common law prerogative to disregard statutory rules which would otherwise operate between private individuals, when compliance with statutory rules would hamper the State in the normal performance of the task of Government".

Labuschagne ${ }^{41}$ explains that an analysis of Roman and Roman-Dutch law indicates that there is very little support for the existence of such a

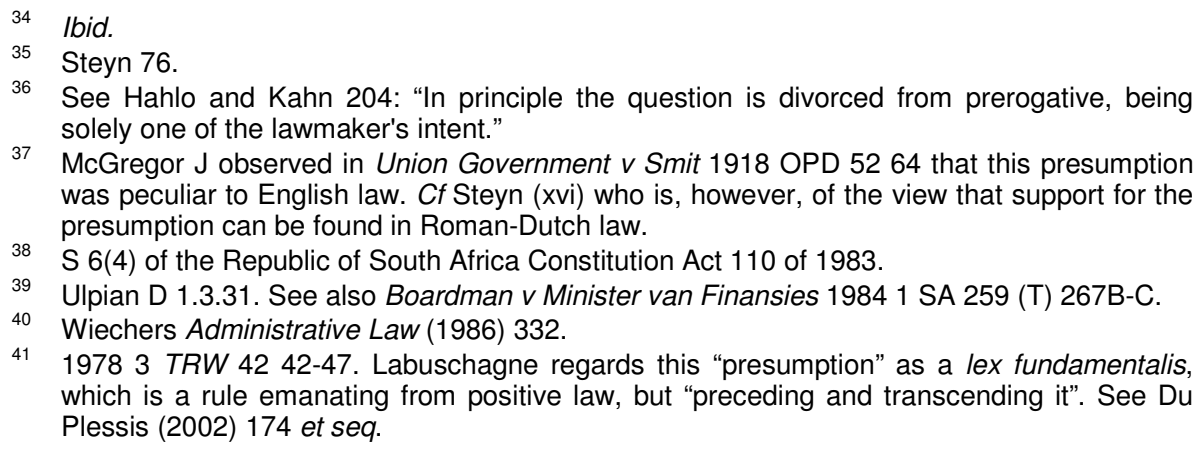

4119783 TRW 42 42-47. Labuschagne regards this "presumption" as a lex fundamentalis, which is a rule emanating from positive law, but "preceding and transcending it". See Du Plessis (2002) 174 et seq. 
presumption in these sources. This is contradictory to Steyn's thesis. ${ }^{42}$

An exposition of this presumption is found in Union Government $v$ Tonkin, ${ }^{43}$ read together with South African Railways and Harbours $v$ Smiths Coasters (Pty) $L t d .{ }^{44}$ In the former the court held that "the intention that the Crown should be bound, ... must clearly appear either from the language used, or from the nature of the enactment" ${ }^{45}$ In the latter case De Villiers CJ pointed out that:

“In Hornsey Urban District Council v Hennel ... Lord Alverstone CJ ... proceeds to point out that, in more than one of the English cases, the contention has been advanced that the rule exempting the Crown from the operation of a statute which does not name it, was not applicable to a statute which would not have the effect of imposing a burden on the Crown, or interfering with its property, or with some prerogative right belonging to the Crown and not shared by the subject."

The above dictum was at one time considered to restrict the presumption to the extent, described by De Villiers CJ above, to those circumstances involving onerous provisions or a constitutional prerogative. However, De Villiers CJ left this question open, since it did not arise for decision in the case before him. The matter was, however, taken further and settled in Evans $v$ Schoeman $N O{ }^{46}$ in which the erstwhile Appellate Division, relying on the Privy Council decision in Province of Bombay $v$ Municipal Corporation of the City of Bombay, ${ }^{47}$ came to the conclusion that the presumption is not restricted to cases involving the prerogative. ${ }^{48}$

Nevertheless, the jurisprudential explanation of the presumption remains problematic, as is apparent from the observation of Nestadt $\mathrm{J}$ in Oertel $v$ Director of Local Government ${ }^{49}$ that

"the limitation on the running of prescription ... against the State ... rests ... on broad considerations of public policy akin to the Crown prerogative of English law".

In this case Nestadt $J$ was unable to identify the exact juridical basis of the presumption. ${ }^{50}$

The formulation of this principle by the wording "the State is not presumed to be bound by statute" even in the past, has been highly problematic and

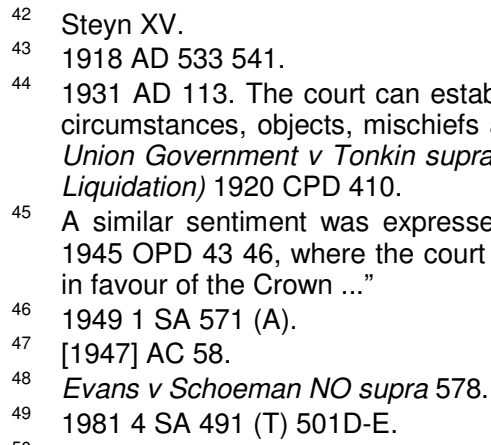
Liquidation) 1920 CPD 410. in favour of the Crown ..."

$46 \quad 19491$ SA 571 (A).

47 [1947] AC 58.

48 Evans $v$ Schoeman NO supra 578.

4919814 SA 491 (T) 501D-E.

$1931 \mathrm{AD}$ 113. The court can establish the intention of the legislature from the surrounding circumstances, objects, mischiefs and consequences of the enactment. See in this regard Union Government v Tonkin supra 541; and Receiver of Revenue v Barlinski \& Co Ltd (In

45 A similar sentiment was expressed in South African Railways and Harbours $v$ Coleman 1945 OPD 4346 , where the court observed that "one should always proceed with the bias

50 lbid. 
misleading and it flies in the face of state liability, which is the very basis of all state administrative actions that are based on the fundamental principle of legality ${ }^{51}$ which is now inextricably part of the Constitution as well as the common law, as now interpreted in the light of section 39(2) of the Constitution. For this reason the presumption should most certainly not be applied in a mechanical way. In this regard MacDonald JP ${ }^{52}$ sounded a note of warning:

"Where the State is expressly or impliedly exempted from liability under statutory provisions, the exemption is enjoyed by the State and not by servants of the State. Servants of the State are not a privileged class of person as, for example, are members of the diplomatic corps. An agent or servant of the State, only escapes criminal liability if the act in question was expressly or impliedly authorized by the State and as such is an act of the State itself."

In the light of the inordinate controversy during the last decade of apartheid rule relating to notorious hit squads, ${ }^{53}$ this is a fundamental principle that all civil servants should bear in mind. The formula "the State is not presumed to be bound" also creates the unfortunate impression of state immunity that is anathema to the ethos and practice of the rule of law, as well as to the practice of limited government or constitutionalism, entrenched in the Constitution.

Du Plessis suggests that the manner in which the presumption should be applied should be by "striking a balance between the provisions of an enactment and the solutions called for by the peculiarities of the concrete situation to which they are applied". ${ }^{54}$ Such a modus operandi is clear from the following observation made by the court in $R v$ Church: $:^{55}$

"It is ... not difficult to imagine circumstances when considerations of State of far greater importance than individual rights of the landowner would have to be disregarded if the section in question were made applicable to the Crown and its servants."

Indeed, it is submitted that a concatenation of factors must be present before the presumption becomes operative. Wiechers suggested and explained that a reversal ${ }^{56}$ of the wording of the presumption would more accurately reflect the legal position, ${ }^{57}$ namely that the State is presumed to be bound by all laws except in those circumstances which obtain for private persons as well, and which, if the state were indeed bound, would hamper it in the fulfilment of an essential function. ${ }^{58}$

51 In this regard see the comment by Van Deventer AJ in Raats Röntgen and Vermeulen (Pty) Ltd v Administrator, Cape 19911 SA 827 (C) 842: "Apart from its moral unacceptability, the presumption in such cases is placed in confrontation with other time-tested rules of construction deriving from the common law ..." $S$ v Reed 19722 SA 34 (RA) 35F-G.

See Lawrence Death Squads Apartheid's Secret Weapon (1990).

Du Plessis (1986) 79.

1935 OPD 7073.

In this regard see Labuschagne 19783 TRW 65.

Wiechers 322.

58 Wiechers 333 . 
This presumption in its unqualified form has rightly been criticized by the English legal philosopher, Friedmann ${ }^{59}$ In its place he suggests a compromise between governmental freedom in matters of high policy and submission of the State to the rule of law. There should only be a presumption against the State's being bound where governmental aspects of the prerogative (notably foreign affairs) would be affected, and not where State activity puts the executive on the same level as private individuals as is particularly the case regarding industrial and commercial activities.

\section{THE ADOPTION OF A MORE FLEXIBLE APPROACH}

Over the years, prior to the new constitutional dispensation starting in 1994, there was some support for a more flexible approach to the presumption in our case law. Van den Heever $J$ (as he was then) opined that "it is conceivable ... that certain provisions in an Act may be binding on the Crown while others may not". ${ }^{60}$ Wiechers's explanation, referred to above, that a reversal of the wording of the presumption would more accurately reflect the legal position is indeed a rational and jurisprudentially accurate exposition of a complex legal situation which cannot merely be legally regulated by a simplistic and distorted formula that "the State is not bound by statute". Trengove $\mathrm{J},{ }^{61}$ however, has commented on Wiechers's view by saying that "whatever the criticism may be, this court must approach the point in issue on the basis of approved precedents". ${ }^{2}$ He unfortunately declined to express any view on the thesis proposed by Wiechers. Precedents can of course establish bad law, and then it is the task of the courts to use their inherently creative powers to comment, criticize and ultimately remould the law into something that is more in accordance with the principles and spirit of our common law and in the light of our new dispensation in accordance with the values in the new Constitution, as required by section 39(2) of the Constitution. This is essentially a creative task for the Constitutional Court, but also for other High Courts in the light of section 39(2) of the Constitution, as indicated above.

Even before 1994 a more flexible approach to the operation of precedent in general was taking root in our jurisprudence. ${ }^{63}$ Steyn's celebrated approach to the discredited versari doctrine is an apt example of this creative power. ${ }^{64}$ Nevertheless, Van Tonder ${ }^{65}$ and Du Plessis ${ }^{66}$ argue that "an alteration of its basis or content at this stage rests with the legislature

\footnotetext{
Friedmann Law in a Changing Society (1959) 391.

South African Railways and Harbours $v$ Coleman supra 46. See also $R v$ Thomas 19541 SA 185 (SWA) 187.

$S$ v De Bruin 19753 SA 56 (T).

62 S v De Bruin supra 58-61.

63 See Dendy "Municipal Immunity for Non-repair of Streets: Overruling the Appellate Division" 1988105 SALJ 177.

64 Steyn CJ in S v Van der Mescht 19621 SA 521 (A).

65 See the preface to Steyn Interpretation of Statutes XV.

66 (1986) 78-89.
} 
rather than the courts ..." Wiechers's view has indeed been adopted in the judgment of Van Deventer AJ in Raats Röntgen and Vermeulen (Pty) Ltd v Administrator, Cape ${ }^{67}$ who commented that

"[t]here is much to be said for Wiechers's view ... that the presumption should be reversed and that the State should presumably be bound by all its laws except those which, if the State were to obey them at all times, would impede the proper execution of its functions".

However, when the above judgment was taken on appeal, in Administrator, Cape $v$ Raats Rontgen \& Vermeulen (Pty) Ltd ${ }^{68}$ was overturned by the Appellate Division and as a result the application of the presumption in its traditional form confirmed.

$S v$ De Bruin $^{69}$ is an exemplary case where it could justifiably be inferred that the State should not be bound. It was held that although it was not the intention of the legislature that the speed regulations promulgated in terms of Act 89 of 1970 should bind the State, they are indeed binding on civil servants acting within the scope of their duties. This applies unless they have specifically or by necessary implication been authorized by the State not to comply with them. In this case the appellant, a policeman, had failed to comply with the regulations while executing his duties. It was clear that the relevant speed restrictions would indeed have impeded him in the fulfilment of his duties, and consequently it was correctly held that he was not subject to them at the time. ${ }^{70}$

In marked contrast, $R v$ De Beer ${ }^{71}$ involved the disregard by a postman, and not a policeman, of speed restrictions. Here it is clear that the circumstances did not rationally justify exoneration from compliance with the provisions of the law as Feetham $\mathrm{J}$ found. However, in contrast to the sentiment expressed by Feetham $J$, in the last-mentioned case, in Boardman $v$ Minister van Finansies ${ }^{72}$ Van Dyk $\mathrm{J}$ found that bonus bonds were not a lottery and hence they did not contravene provisions of the Gambling Act. ${ }^{73}$ Nevertheless, even if they were, by virtue of the maxim princeps legibus solutus est the State was not bound by the prohibition against gambling.

Steyn $^{74}$ was of the viewpoint that a similar presumption applies to subordinate bodies, such as local authorities, to the effect that they do not intend to bind themselves by their own regulations or by-laws since, according to him, the relationship between such authorities and persons within their jurisdiction does not differ, in principle, from that of the State to

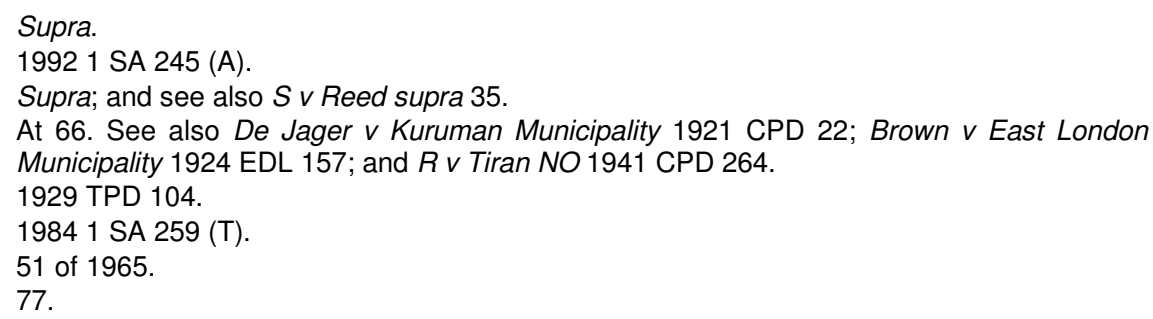


its subjects. ${ }^{75}$ However, the view adopted by Van Deventer AJ in the Raats Röntgen case to the effect that "provincial administrations are bound by laws of Parliament" ${ }^{76}$ is preferable. Regrettably this was rejected by the erstwhile Appellate Division, as indicated above. However, in the light of our new constitutional dispensation and the entrenchment of the rule of law in section 1 (c) of the Constitution, it is extremely unlikely that the Constitutional Court would continue to uphold this presumption in an unqualified way. This is also the view of Du Plessis who comments in this regard that "[t]he moment for what Wiechers foresaw more than a decade and a half ago, has probably come". ${ }^{77}$

Labuschagne ${ }^{78}$ adopted a similar view and relied on examples from the post-1994 case law in support of this contention that the conventional presumption has become an anachronism in our constitutional state. ${ }^{79}$ In this regard he refers to two cases: Somfongo $v$ Government of $R S A^{80}$ and Minister of Water Affairs and Forestry $v$ Swissborough Diamond Mines (Pty) $L t d .^{81} \mathrm{He}$ argues further that the Constitution requires that the legislature, the executive and the judiciary are bound by the Bill of Rights and consequently the presumption is insupportable. Also human rights values require it to be bound.

In the former case the Military Council of Transkei had agreed to waive compliance with procedures relating to promotions. Promotions took place disregarding procedures. As a result these promotions were challenged in the courts. Although the court followed the judgment in Raats Röntgen and Vermeulen (Pty) Ltd $v$ Administrator, Cape ${ }^{82}$ and held that the State was not bound by its own enactments, except by express words or necessary implication, that is, if the intention to be bound appeared clearly from the enactment itself, in this case it was found that the State was indeed bound by implication, although there was nothing expressly so stated in the provisions of the Act. Discipline in the police force itself and the relationship between the force and the community required this.

In the latter case (Swissborough Diamond Mines), adverted to above, the court per Joffe $\mathrm{J}$ dismissed a claim in respect of State privilege relating to disclosure or production of official documents that allegedly would be prejudicial to the public interest. Both these cases reflect greater

75 See Hahlo and Kahn 204-205: "An enactment does not apply to the State or its executive arm or to a provincial council, local authority or other public body from which it emanates." In regard to the Provincial Councils see Transvaal Provincial Administration v Klerksdorp Municipality 1923 TPD 475; Natal Provincial Administration v SAR \& H 1936 NPD 643; and Van der Linde $v$ Calitz 19672 SA 239 (A) 260-261.

76 Raats Röntgen and Vermeulen (Pty) Ltd v Administrator, Cape supra 848E-F; and see Du Plessis (1986) 78.

77 Du Plessis (2002) 177.

78 "Die Uitlegvermoede Teen Staatsgebondenheid in 'n Regstaat: 'n Regsantropologiese Perspektief" 2000 SA Public Law 304.

79 Labuschagne 2000 SA Public Law 319.

8019954 SA 738 (Tk SC).

19992 SA 279 (T) 343.

82 Supra 262 A-D. 
circumspection in relation to claims by the state of immunity from obligation.

Labuschagne ${ }^{83}$ suggests a different approach, namely that the function of the State must be considered as giving and maintaining of normative structure for human development. In this light the rule is not a presumption, but rather a condition which precedes positive law and rises above it. ${ }^{84}$ In this regard he employs the term lex fundamentalis used by the RomanDutch scholars. In effect each set of circumstances must be considered to determine whether the State should be bound or not and that the enquiry should not commence with a presumption.

Obviously, a statute may expressly state that it shall be binding on the State. This is the position in regard to the Interpretation Act. ${ }^{85}$ The question must be asked whether foreign states are bound by our law. In international law there are two basic approaches: ${ }^{86}$ the older approach, which accords absolute immunity to foreign states, and the newer approach which accords relative immunity. In general there is a move away from absolute immunity.

\section{CONCLUSION}

Section 2 of the Constitution declares it to be supreme. It enshrines the rule of law in it and also gives expression to it in the provisions of the Bill of Rights. Section 1 of the South African Constitution prescribes the rule of law as one of the seminal libertarian values on which the Constitution is founded. The concept of the rule of law $^{87}$ is a fundamental value that underlies "an open and democratic society based on dignity, equality and freedom", and must be promoted when interpreting the provisions of the Bill of Rights. Furthermore, section 39(2) of the Constitution stipulates that the principles and rules of our common law must be developed in accordance with the spirit and ethos of the fundamental rights in the Constitution. This poses a formidable challenge to the presumption that the State is not bound by legislation for the following reasons as Botha explains: ${ }^{88}$

(a) Section 8(1) of the Constitution explicitly states that State organs of whatever nature are legally bound by the Bill of Rights. Section 2 of the Constitution declares that it is supreme law, and that all conduct of any kind must be in accordance with the ethos, purport and objects of the fundamental rights entrenched in the Bill of Rights; and

(b) Accountability and transparency are inextricably intertwined with the fabric of the Constitution. The Constitution renders the executive accountable for its conduct, which is justiciable and must be in accordance with the letter and spirit of the rule of law, in accordance with

19783 TRW 65.

Ibid.

S 24 of Act 33 of 1957.

36 See Sinclair "The European Convention on State Liability" 197322 The International and Comparative Law Quarterly 254; and see also Labuschagne 19783 TRW 49.

87 See Froneman "Die Grondwet en die 'Rule of Law'” 199530 The Magistrate 21.

88 Botha 92. 
the philosophy of constitutionalism. The South African Parliament, unlike Parliament at Westminster, is no longer sovereign and there is a new libertarian jurisprudence, premised on constitutional and jurisprudential justification rather than on authority.

In the light of the above, Wiechers's explanation that the presumption should indeed be the converse of the traditional approach, is indeed in accordance with the new constitutional dispensation. This is endorsed by $\mathrm{Du}$ Plessis, ${ }^{89}$ who has commented that:

"In short, a state defined by its own constitution as a 'democratic state founded on the values of [s]upremacy of the Constitution and the rule of law' most certainly is a constitutional state (Rechtstaat) heedful of the principle of legality. This observation is confirmed by the constitutional demand for the accountability of the public administration. The moment for what Wiechers foresaw more than a decade and a half ago, has probably come."

This idea is clearly reflected in the Constitutional Court's judgment in Fedsure Life Assurance Ltd v Greater Johannesburg Metropolitan Council, ${ }^{90}$ in which the principle of legality was explained as follows:

"It seems central to the conception of our constitutional order that the Legislature and Executive in every sphere are constrained by the principle that they may exercise no power and perform no function beyond that conferred upon them by law. At least in this sense, then, the principle of legality is implied within the terms of the Interim Constitution. Whether the principle of the rule of law has greater content than the principle of legality is not necessary for us to decide here. We need merely hold that fundamental to the interim constitution is the principle of legality."

From the above important quotation, it is manifestly clear that all organs of State in the new constitutional dispensation should indeed be bound by legislation, unless it can be manifestly demonstrated that in particular circumstances, the State organ concerned, would be hampered in the execution of its duties and functions, if it were indeed bound. This is, it is submitted, something that would have to be proved, and cannot merely be presumed. Both the letter and spirit of the Constitution will not tolerate the lawlessness of State organs. This means that the unqualified presumption that the State is not bound by legislation in its traditional form is no longer valid and is incompatible with nature and operation of the presumptions in general as they now apply in of the Constitution and the common law as developed in terms of section 32(2) of the Constitution. Its application in the present jurisprudential and constitutional dispensation would be anachronistic.

(2002) 177.

19991 SA 374 (CC) par 58. See also in this regard Mohamed $v$ President of the RSA 2001 7 BCLR 685 (CC). In this case the Constitutional Court found that the handing over of a suspect to a foreign government agency was unlawful. In this regard the court commented that (par 68) "The legitimacy of the constitutional order is undermined rather than reinforced when the state acts unlawfully." 